\title{
INFLUENCE OF SOME NITROGEN FERTILIZATION RATES AND APPLICATION METHODS ON GROWTH, YIELD AND YIELD COMPONENTS OF ONION
}

\author{
Abo-Dahab, A.M.A., R. A. Marey and L. S. M. Geries \\ Onion Res. Dept., Field Crops Res. Institute, Agric. Res. Center \\ Giza, Egypt
}

\begin{abstract}
This investigation was conducted at Sids Agricultural Research Station, Bani-Swief Governorates, during two seasons of 2012/2013 and $2013 / 2014$, to evaluate the effect of six nitrogen treatments $(60 \mathrm{~kg} \mathrm{~N}$ without starter fertilizer, $60 \mathrm{~kg} \mathrm{~N}$ with starter fertilizer, $90 \mathrm{~kg} \mathrm{~N}$ without starter fertilizer, $90 \mathrm{~kg} \mathrm{~N}$ with starter fertilizer, $120 \mathrm{~kg} \mathrm{~N}$ without starter fertilizer and $120 \mathrm{~kg} \mathrm{~N}$ with starter fertilizer) and three application methods (broadcasting, side dressing and top dressing) on vegetative growth characters, yield and yield components as well as quality and storability of onion.
\end{abstract}

The obtained results could be summarized as follow:

- The obtained data revealed that plant height, No. of leaves/plant, bulb diameter, bulb length, bulb weight and No. of days to maturity were significantly affected by nitrogen dose in both seasons.

- Adding the highest nitrogen dose of $120 \mathrm{~kg} \mathrm{~N}$ with starter fertilizer gave the highest values of plant height, No. of leaves per plant, bulb diameter, plant weight and No. of days to maturity in both seasons.

- Adding of nitrogen by top dressing method appeared the largest values in respect to all vegetative growth characters, except for bulb diameter in the first season.

- Nitrogen dose significantly affected bulb weight, total yield/fed., marketable yield/fed.and culls yield in both seasons.

- The highest values of bulb weight, total yield and marketable yield were obtained under nitrogen dose of $120 \mathrm{~kg} \mathrm{~N}$ with starter fertilizer in both seasons.

- Application of nitrogen fertilizer by top dressing methods achieved the maximum values of bulb weight, total yield and marketable yield in both seasons.

- Adding of $120 \mathrm{~kg} \mathrm{~N} / \mathrm{fed}$. with starter fertilizer achieved the maximum values of TSS\% in both seasons and dry matter \% in the second season.

- The largest values of TSS\% and dry matter \% were obtained by adding nitrogen fertilizer by top dressing method in both seasons.

- After storing for two months the lowest values of weight loss \% were observed under nitrogen dose of $60 \mathrm{~kg} \mathrm{~N} / \mathrm{fed}$. without starter fertilizer, in both seasons.

- Application of nitrogen by top dressing appeared the lowest values of weight loss\% after storing for 2, 4 and 6 months in both season.

- Based on the current experimental results, with regards to the production as well as economic analysis, application of $120 \mathrm{~kg} \mathrm{~N} / \mathrm{fed}$. with starter fertilizer by 
top dressing method may be suggested for maximizing onion production under similar conditions of this work and further investigations are needed to be conducted in other agro ecological zones of Egypt.

Keywords: N-fertilizer; mineral nitrogen fertilizer, application methods; onion and Allium cepa,

\section{INTRODUCTION}

Onion (Allium cepa L.) is one of the most important commercial vegetable crops grown in Egypt. Onion is grown commercially in Egypt due to its multifarious use as local consumption, processing and exportation. It is one of the sources for hard currency, due to the early availability of crop for foreign markets as well as its higher quality compared to other onions, due to its high pungency and long shelfstorage period.

Nitrogen is one of the most important elements in the plant nutrition. Nitrogen plays an important role on promotion of enzymes activity and enhancing the translocation of assimilates and protein synthesis (Devlin, 1986). Onion being among the high nitrogen demanding vegetables, its productivity depends on use of optimum fertilizer rates and if not adequately fertilized, considerable yield losses are apparent (Balemi, 2007). Brewester (1994) cleared that onions are more susceptible to nutrient deficiencies than most crop plants because of their shallow and unbranched root system; hence they require and often respond well to addition of fertilizers. Hence, there is an urgent need to identify the optimum $\mathrm{N}$ level for better productivity of onion in the area (Abdissa et al., 2011).

Vegetative growth of onion plants was improved by nitrogen application. Abdissa et al. (2011) revealed that regardless of the rate of application, $\mathrm{N}$ fertilization increased bulb diameter and average bulb weight by about 12 and $21.5 \%$, respectively over the control. Mohamed and Hemida (2004) showed that increasing nitrogen levels were accompanied with stimulating plant height, number of leaves per plant, total and exportation yield, bolters\% and bulb weight. Number of days to maturity and percentage of doubles tended to decrease with reducing $\mathrm{N}$ levels, and excessive $\mathrm{N}$ (120 kg/fed.) caused a reduction in yield and delayed on maturity. On the other hand, El-Oksh et al. (1993) revealed that nitrogen application had no significant effect on plant length, number of leaves per plant, plant fresh and dry weight.

The application systems for fertilizers affect largely on the cost of crop production and the efficiency of fertilization. The goal of applying starter fertilizer is to give plants good early season start nitrogen before or just as they are needed. Halvorsan et al. (2001) assessed that onion dry matter accumulation was slow from planting to 
about late May, followed by a rapid increase in biomass production and $\mathrm{N}$ uptake. Experiments indicate that onions grow better when supplied with ammonium rather than $\mathrm{N}$ at the seedling stage (Abbes et al., 1995).Although the amounts of $\mathrm{N}$ required during the early stages of crop growth are small, the nitrate concentrations in the soil need to be high to ensure optimum $\mathrm{N}$ uptake by the developing root system. If these needs are not met, the crop can suffer a temporary $\mathrm{N}$ deficiency that can irreversibly depress growth and final yield (Burns, 1990). The time and method of fertilizer application depend on planting methods, nature of fertilizer, soil type and the differences between crops in density and nutrient requirements through their growth stages (Brewster, 2008). Watson (2010) revealed that concentrating nitrogen fertilizer applications closer to the base of the tree may be able to take advantage of naturally higher root density, in addition to any further root stimulation resulting. Brewster (2008) cleared that it is necessary to split $\mathrm{N}$ applications, typically applying $60-80 \mathrm{~kg} / \mathrm{ha}$ mixed into the soil as a base application just before sowing, and a similar amount broadcast when the plants are about $10 \mathrm{~cm}$ tall.Also, it was found that improved recovery of mineral $\mathrm{N}$ from soil can be achieved using liquid ammonium phosphate starter fertilizer injected $25 \mathrm{~mm}$ below the seed at sowing time (Stone, 2000). Brewster (2008) showed that the accelerated early growth for onion crop can result in higher bulb yields at lower $\mathrm{N}$ levels than with broadcast fertilizer $\mathrm{N}$ alone. The faster early growth using starter fertilizer results in the earlier attainment of a high Leaf Area Index (LAI), which causes earlier bulb maturity (Brewster et al., 1992). Brewster (2008) elucidated that starter fertilizers combined with injection of further fertilizer after emergence may make it possible to grow high-yielding onion crops at lower levels of available soil NPK than is possible using conventional broadcast fertilizer. Stone (2000) cleared that ammonium phosphate consistently improved early growth and final yield of bulb onion and crisp lettuce compared to broadcast ammonium nitrate. A reduced $\mathrm{N}$ input system based on starter fertilizers is likely to be acceptable to the industry, but would rely on a method to predict how much $\mathrm{N}$ is required to supplement that provided. For these reasons, starter fertilizers are now widely used commercially in the UK on bulb and salad onion and leek crops (Brewster, 2008).

The application method for fertilizers is very important for plant, as it had direct effect on the availability of nutrients for plants, and on fertilizers losses from soil. The used application method should maximize nutrient availability to onion plants roots and minimize losses to the environment. Latif et al. (2003) reported that the fertigation enhanced fresh and dry matter yield of onion over the broadcasting.

The objective of this research was to determine the optimum nitrogen dose and application method, which should maximize nutrient 
availability to onion plants roots and minimize losses to the environment, which should reflect on growth, yield and its components as well as quality and storability of onion bulbs.

\section{MATERIAL AND METHODS}

This study was carried out at the Experimental Farm of Sids Agricultural Research Station, Bani-Swief Governorates, Middle Egypt, during two winter seasons of 2012/2013 and 2013/2014. The experiment was conducted to evaluate the effect of some nitrogen doses and three application methods on vegetative growth characters, yield and yield components as well as quality and storability of onion (Giza 6 Mohassan cultivar). Seed were sown in the nursery on the second week of September in the each growing season. Transplanting was done on $1^{\text {st }}$ of November in both seasons.

Some physical and chemical analyses of the experimental soil were listed in Table (1).

Table (1): Some physical and chemical analysis of the experimental soil at 0$30 \mathrm{~cm}$ depth in 2012-2013 and 2013-2014 seasons

\begin{tabular}{|c|l|c|c|}
\hline \multicolumn{2}{|c|}{ Determination } & $\mathbf{2 0 1 2 - 2 0 1 3}$ season & 2013-2014 season \\
\hline \multirow{4}{*}{ Mechanical analysis } & Sand & 18.9 & 17.9 \\
\cline { 2 - 4 } & Silt & 33.3 & 32.6 \\
\cline { 2 - 4 } & Clay & 47.8 & 49.5 \\
\cline { 2 - 4 } & Texture class & Clay & Clay \\
\hline \multirow{5}{*}{ Chemical analysis } & O.M\% & 1.93 & 1.68 \\
\cline { 2 - 4 } & E.C ds/m & 1.44 & 7.52 \\
\cline { 2 - 4 } & $\mathrm{pH}$ & 7.9 & 40.9 \\
\cline { 2 - 4 } & Available N $(\mathrm{ppm})$ & 44.1 & 12.4 \\
\cline { 2 - 4 } & $\mathrm{P}(\mathrm{ppm})$ & 11.9 & 196 \\
\cline { 2 - 4 } & $\mathrm{K}(\mathrm{ppm})$ & 193.2 & \\
\hline
\end{tabular}

This experiment included 18 treatments, which were the combination between six nitrogen dose and three application methods for nitrogen fertilizer. These treatments were arranged in split plot design with four replications. The main plots were devoted to nitrogen dose as follow:

- $60 \mathrm{~kg} \mathrm{~N}$ without starter fertilizer (Adding $30 \mathrm{~kg}$ nitrogen as ammonium nitrate after 30 days from transplanting $+30 \mathrm{~kg} \mathrm{~N}$ after 60 days as ammonium nitrate).

- $60 \mathrm{~kg} \mathrm{~N}$ with starter fertilizer (Adding $20 \mathrm{~kg}$ nitrogen as ammonium sulfate before transplanting $+20 \mathrm{~kg}$ nitrogen as ammonium nitrate after 30 days $+20 \mathrm{~kg}$ nitrogen as ammonium nitrate after 60 days)

- $90 \mathrm{~kg} \mathrm{~N}$ without starter fertilizer (Adding $45 \mathrm{~kg}$ nitrogen as ammonium nitrate after 30 days from transplanting $+45 \mathrm{~kg} \mathrm{~N}$ after 60 days as ammonium nitrate).

- $90 \mathrm{~kg} \mathrm{~N}$ with starter fertilizer (Adding $20 \mathrm{~kg}$ nitrogen as ammonium sulfate before transplanting $+35 \mathrm{~kg}$ nitrogen as ammonium nitrate after 
30 days from transplanting $+35 \mathrm{~kg} \mathrm{~N}$ after 60 days as ammonium nitrate).

- $120 \mathrm{~kg} \mathrm{~N}$ without starter fertilizer (Adding $60 \mathrm{~kg}$ nitrogen as ammonium sulfate before transplanting $+60 \mathrm{~kg}$ nitrogen as ammonium nitrate after 30 days $+60 \mathrm{~kg}$ nitrogen as ammonium nitrate after 60 days).

- $120 \mathrm{~kg} \mathrm{~N}$ with starter fertilizer (Adding $20 \mathrm{~kg}$ nitrogen as ammonium sulfate before transplanting $+50 \mathrm{~kg}$ nitrogen as ammonium nitrate after 30 days $+50 \mathrm{~kg}$ nitrogen as ammonium nitrate after 60 days).

While the assessed application methods occupied sub plots as follows:

- Broadcasting, which mean even and uniform spreading fertilizers by hand over the entire surface of field in the standing crop

- Side dressing, which means spreading of fertilizers in the standing crop, as the fertilizer is put in continuous on both sides of the row.

- Top dressing, which means spreading of fertilizers in the standing crop, as the fertilizer is put in continuous on the top of the row.

The plot size was $10.5 \mathrm{~m}^{2}$ ( $3.5 \mathrm{~m}$ length and $3 \mathrm{~m}$ in width) including five ridges with $60 \mathrm{~cm}$ apart between ridges (1/400 fed.). Uniformed seedlings were transplanted after hardening on both sides of ridges 7 $\mathrm{cm}$ apart. Calcium super phosphate $\left(15.5 \% \mathrm{P}_{2} \mathrm{O}_{5}\right)$ was added during land preparation at the rate of $300 \mathrm{~kg} / \mathrm{fed}$. and potassium sulfates $\left(48 \% \mathrm{~K}_{2} \mathrm{O}\right)$ at rate of $100 \mathrm{~kg} / \mathrm{fed}$. during land preparation. Other cultural practices for growing onion were conducted as recommended for onion production at middle Egypt region.

\section{Data recorded:}

\section{A- Vegetative growth characteristics:}

After 120 days from transplanting, 10 randomly selected plants were taken from each plot to measure plant height $(\mathrm{cm})$, bulb length $(\mathrm{cm})$, No. of leaves/plant, bulb diameter $(\mathrm{cm})$, plant weight (g), bulb weight (g), days to maturity. Number of days from transplanting to bulb maturity was counted. Maturity stage was determined based on both softening of bulb neck and 50\% topdown of bulb leaves.

\section{B- Bulb yield and its components:}

At harvest time, all plants in the experimental plot were uprooted and the following data were recorded:

1- Average bulb weight ( $\mathrm{g}$ ): It was calculated by dividing weight of single bulbs by its number.

2- Total yield ( $\mathrm{t} / \mathrm{fed}$.): It was calculated on basis of yield for the experimental plot in $\mathrm{t} / \mathrm{fed}$.

3- Marketable yield ( $\mathrm{t} / \mathrm{fed}$.): It was determined as the weight of single bulb yield for each experimental plot.

4- Culls yield ( $\mathrm{t} / \mathrm{fed}$.): It includes bulbs of less than $3 \mathrm{~cm}$ diameter, doubles, bolters, off-color and scallions. 


\section{C- Bulb quality characteristics:}

At harvest, a random sample of 5 bulbs was taken from each plot, to determine the following character:

1- Total soluble solids (T.S.S): It was determined immediately after harvest by a hand refractometer in representative sample of ten bulbs according to A.O.A.C. (1975).

2- Percentage of dry matter in bulbs (D.M. \%): It was determined by estimating the loss in sample of bulbs fresh weight after drying for four hours at $105^{\circ} \mathrm{C}$ and then at $70^{\circ} \mathrm{C}$ in a drying oven, according to the following formula:

\section{D- Storage ability:}

$$
\text { D.M. } \%=\frac{\text { Sample dry weight }}{\text { Sample fresh weig } \mathrm{ht}} \times 100
$$

Marketable yield of each plot was placed in common burlap bags and kept under normal storage conditions. Weight of losses bulb $\%$ after 60,120 and 180 days was recorded for each plot and divided by marketable yield $x 100$.

\section{E. Economic analysis:}

Economic analysis was performed to calculate net return and the benefit cost ratio with respect to each treatment.

\section{Cost of cultivation:}

Cost of cultivation was calculated on the basis of local charges for different agro-inputs, i.e. labor, fertilizer, compost, and other necessary materials. Cost of cultivation of fourteen treatments was calculated separately.

\section{Gross return:}

Economic yield (onion bulbs) of onion was converted into gross return (L.E./fed.) on the basis of local market price.

\section{Net return:}

It was calculated by subtracting the cost of cultivation from the gross return.

\section{Benefit cost ratio:}

It was calculated by the formula, $\mathrm{B}: \mathrm{C}$ ratio $=$ Gross return/Cost of cultivation.

\section{Statistical analysis:}

All collected data were subjected to analysis of variance according to Snedecor and Cochran (1980). Significance between different means was tested using LSD method according to Walter and Duncan (1969). 


\section{RESULTS AND DISCUSSION}

\section{A- Effect of nitrogen dose and application method on vegetative growth characters of onion:}

The obtained data in Table (2 and 3) clear that the vegetative growth characters (plant height, No. of leaves/plant, bulb diameter, bulb length, bulb weight and No. of days to maturity) were significantly affected by nitrogen dose, these were true for all growth characters in both seasons. Adding the highest nitrogen dose of $120 \mathrm{~kg} \mathrm{~N}$ with starter fertilizer gave the highest values of plant height (76.62 and $78.88 \mathrm{~cm})$, No. of leaves per plant $(9.84$ and 10.14), bulb diameter $(6.67$ and $6.84 \mathrm{~cm})$, plant weight $(214.67$ and $211.49 \mathrm{~g})$ and No. of days to maturity (146.75 and 143.42) in the first and second seasons, respectively

Table (2): Effect of nitrogen dose and application method on plant height $(\mathrm{cm})$, No. of leaves/plant and bulb diameter (cm) of onion in 2012/2013 and 2013/2014 seasons

\begin{tabular}{|c|c|c|c|c|c|c|c|}
\hline \multirow[b]{2}{*}{$\begin{array}{l}\text { Nitrogen dose } \\
(\mathbf{k g} / \mathrm{fed} .)\end{array}$} & \multirow[b]{2}{*}{ Application method } & \multicolumn{3}{|c|}{$2012 / 2013$} & \multicolumn{3}{|c|}{ 2013/2014 } \\
\hline & & $\begin{array}{c}\text { Plant } \\
\text { height } \\
(\mathrm{cm})\end{array}$ & $\begin{array}{c}\text { No. of } \\
\text { leaves/ } \\
\text { plant }\end{array}$ & $\begin{array}{c}\text { Bulb } \\
\text { diameter } \\
\text { (cm) }\end{array}$ & $\begin{array}{l}\text { Plant } \\
\text { height } \\
(\mathrm{cm})\end{array}$ & $\begin{array}{c}\text { No. of } \\
\text { leaves/ } \\
\text { plant }\end{array}$ & $\begin{array}{c}\text { Bulb } \\
\text { diameter } \\
\text { (cm) }\end{array}$ \\
\hline \multirow{4}{*}{$\begin{array}{l}60 \text { without } \\
\text { starting } \\
\text { fertilizer }\end{array}$} & Broadcasting & 41.80 & 6.20 & 3.88 & 40.23 & 6.20 & 3.98 \\
\hline & Side dressing & 45.45 & 5.88 & 4.25 & 40.31 & 5.95 & 4.23 \\
\hline & Top dressing & 41.00 & 6.83 & 4.15 & 42.05 & 6.68 & 4.15 \\
\hline & Mean & 42.75 & 6.30 & 4.09 & 40.86 & 6.28 & 4.12 \\
\hline \multirow{4}{*}{$\begin{array}{l}60 \text { with } \\
\text { starting } \\
\text { fertilizer }\end{array}$} & Broadcasting & 47.23 & 6.28 & 4.50 & 44.75 & 6.25 & 4.30 \\
\hline & Side dressing & 46.73 & 6.60 & 4.53 & 48.25 & 6.88 & 4.05 \\
\hline & Top dressing & 49.13 & 7.10 & 4.43 & 50.05 & 7.25 & 4.48 \\
\hline & Mean & 47.69 & 6.66 & 4.48 & 47.68 & 6.79 & 4.28 \\
\hline \multirow{4}{*}{$\begin{array}{l}90 \text { without } \\
\text { starting } \\
\text { fertilizer }\end{array}$} & Broadcasting & 56.30 & 6.83 & 5.05 & 59.00 & 6.68 & 4.68 \\
\hline & Side dressing & 57.05 & 6.18 & 5.43 & 57.08 & 6.13 & 4.40 \\
\hline & $\begin{array}{l}\text { Top dressing } \\
\end{array}$ & 58.88 & 7.33 & 5.08 & 61.93 & 7.05 & 5.23 \\
\hline & Mean & 57.41 & 6.78 & 5.18 & 59.33 & 6.62 & 4.77 \\
\hline \multirow{4}{*}{$\begin{array}{l}90 \text { with } \\
\text { Starting } \\
\text { fertilizer }\end{array}$} & \begin{tabular}{|l} 
Broadcasting \\
\end{tabular} & 57.08 & 6.53 & 4.93 & 57.95 & 6.60 & 5.00 \\
\hline & Side dressing & 57.15 & 7.40 & 4.98 & 61.40 & 7.18 & 5.23 \\
\hline & Top dressing & 63.68 & 7.83 & 5.03 & 63.98 & 7.60 & 5.68 \\
\hline & Mean & 59.30 & 7.25 & 4.98 & 61.11 & 7.13 & 5.30 \\
\hline \multirow{4}{*}{$\begin{array}{l}120 \text { without } \\
\text { starting } \\
\text { fertilizer }\end{array}$} & Broadcasting & 72.05 & 8.83 & 6.15 & 70.68 & 8.50 & 6.00 \\
\hline & Side dressing & 71.78 & 9.20 & 6.08 & 71.60 & 9.10 & 6.05 \\
\hline & Top dressing & 75.98 & 9.18 & 6.33 & 73.70 & 9.33 & 6.20 \\
\hline & Mean & 73.27 & 9.07 & 6.18 & 71.99 & 8.98 & 6.08 \\
\hline \multirow{4}{*}{$\begin{array}{l}120 \text { with } \\
\text { Starting } \\
\text { fertilizer }\end{array}$} & Broadcasting & 72.93 & 9.18 & 6.43 & 75.15 & 9.38 & 6.38 \\
\hline & Side dressing & 76.20 & 9.75 & 6.75 & 78.45 & 10.28 & 6.73 \\
\hline & Top dressing & 80.73 & 10.60 & 6.83 & 83.05 & 10.78 & 7.43 \\
\hline & Mean & 76.62 & 9.84 & 6.67 & 78.88 & 10.14 & 6.84 \\
\hline \multirow{3}{*}{$\begin{array}{l}\text { Means for } \\
\text { application } \\
\text { methods }\end{array}$} & Broadcasting & 57.90 & 7.30 & 5.15 & 57.96 & 7.27 & 5.05 \\
\hline & Side dressing & 59.06 & 7.50 & 5.33 & 59.51 & 7.58 & 5.11 \\
\hline & Top dressing & 61.56 & 8.14 & 5.30 & 62.46 & 8.11 & 5.53 \\
\hline \multirow{3}{*}{ L.S.D. 5\% } & $\mathrm{N}$ doses $(\mathrm{A})$ & 2.27 & 0.34 & 0.49 & 1.87 & 0.41 & 0.27 \\
\hline & Appl. methods (B) & 1.67 & 0.35 & N.S & 2.05 & 0.24 & 0.22 \\
\hline & Interaction (AxB) & 4.10 & N.S & N.S & N.S & N.S & N.S \\
\hline
\end{tabular}

NS indicate not significant at 0.05 .

For bulb length the highest values were obtained by nitrogen treatments of $90 \mathrm{~kg} \mathrm{~N}$ with starter fertilizer in the first season, and by treatment of $120 \mathrm{~kg} \mathrm{~N}$ with starter fertilizer in the second season. Nitrogen dose treatment of $60 \mathrm{~kg} \mathrm{~N}$ without starting dose appeared the lowest values of plant height (42.75 and $40.86 \mathrm{~cm})$, No. of leaves/plant (6.30 and 6.28), bulb diameter $(4.09$ and $4.12 \mathrm{~cm})$, bulb length $(4.18$ and $4.33 \mathrm{~cm}$ ), plant weight ( 152.38 and $153.63 \mathrm{~g}$ ) and days to maturity (107.33 and 106.17), in the first and second seasons, respectively. 
Increasing vegetative growth characters under higher rates of nitrogen may be due to the stimulation effect of nitrogen on building up new cells and increasing the synthesized compounds which induce an increase in plant growth. These results was in harmony with that found by Al-Fraihat (2009) who revealed that increasing nitrogen application rates significantly enhanced plant height, number of green leaves/plant and weight of plant at different stages of onion growth. These results also suggested that adding a part of fertilizer as starter (Adding $20 \mathrm{~kg}$ nitrogen as ammonium sulfate before transplanting) increased the values of all vegetative growth characters under all nitrogen doses (60, 90 and $120 \mathrm{~kg} / \mathrm{fed}$.) in both seasons, except for bulb diameter under dose of $90 \mathrm{~kg} / \mathrm{fed}$. in the first season. These results were in accordance with that obtained by Abbes et al. (1995), who indicated that onions grow better when supplied with ammonium rather than $\mathrm{N}$ at the seedling stage. From the data, it was concluded that the number of days to maturity was increased by increasing nitrogen rate. This result was in coincide with that recorded by Woldetsadik et al. (2003), who found that additional nitrogen to onion plants delayed bulb growth and development.

Table (3): Effect of nitrogen dose and application method on bulb length $(\mathrm{cm})$, plant weight (g) and No. of days to maturity of onion in 2012/2013 and 2013/2014 seasons

\begin{tabular}{|c|c|c|c|c|c|c|c|}
\hline \multirow[b]{2}{*}{$\begin{array}{l}\text { Nitrogen dose } \\
\quad(\mathbf{k g} / \mathrm{fed} .)\end{array}$} & \multirow[b]{2}{*}{$\begin{array}{l}\text { Application } \\
\text { method }\end{array}$} & \multicolumn{3}{|c|}{$2012 / 2013$} & \multicolumn{3}{|c|}{ 2013/2014 } \\
\hline & & $\begin{array}{l}\text { Bulb } \\
\text { length } \\
\text { (cm) }\end{array}$ & $\begin{array}{c}\text { Plant } \\
\text { weight (g) }\end{array}$ & $\begin{array}{l}\text { Days to } \\
\text { maturity }\end{array}$ & $\begin{array}{l}\text { Bulb } \\
\text { length } \\
\text { (cm) }\end{array}$ & $\begin{array}{c}\text { Plant } \\
\text { weight (g) }\end{array}$ & $\begin{array}{l}\text { Days to } \\
\text { maturity }\end{array}$ \\
\hline \multirow{3}{*}{$\begin{array}{c}60 \text { without } \\
\text { starting } \\
\text { fertilizer }\end{array}$} & Broadcasting & 4.05 & 148.10 & 105.00 & 4.28 & 146.65 & 104.75 \\
\hline & Side dressing & 4.05 & 153.35 & 109.75 & 4.43 & 151.93 & 106.00 \\
\hline & Top dressing & 4.45 & 155.68 & 107.25 & 4.30 & 162.30 & 107.75 \\
\hline \multicolumn{2}{|c|}{ Mean } & 4.18 & 152.38 & 107.33 & 4.33 & 153.63 & 106.17 \\
\hline \multirow{3}{*}{$\begin{array}{l}60 \text { with starting } \\
\text { fertilizer }\end{array}$} & Broadcasting & 4.58 & 152.78 & 107.00 & 4.50 & 159.35 & 109.75 \\
\hline & Side dressing & 4.48 & 156.15 & 110.50 & 4.38 & 162.28 & 109.00 \\
\hline & Top dressing & 4.90 & 162.65 & 115.75 & 5.00 & 171.38 & 113.50 \\
\hline \multicolumn{2}{|c|}{ Mean } & 4.65 & 157.19 & 111.08 & 4.63 & 164.33 & 110.75 \\
\hline \multirow{3}{*}{$\begin{array}{l}90 \text { without } \\
\text { starting } \\
\text { fertilizer }\end{array}$} & Broadcasting & 5.08 & 178.38 & 117.25 & 4.78 & 169.58 & 117.00 \\
\hline & Side dressing & 5.25 & 180.68 & 117.75 & 4.98 & 181.00 & 119.75 \\
\hline & Top dressing & 5.03 & 188.95 & 119.75 & 5.38 & 183.93 & 118.25 \\
\hline \multicolumn{2}{|c|}{ Mean } & 5.12 & 182.67 & 118.25 & 5.04 & 178.17 & 118.33 \\
\hline \multirow{3}{*}{$\begin{array}{l}90 \text { with starting } \\
\text { fertilizer }\end{array}$} & Broadcasting & 5.20 & 188.73 & 120.50 & 5.05 & 175.63 & 116.75 \\
\hline & Side dressing & 5.83 & 194.73 & 122.25 & 5.38 & 186.88 & 120.00 \\
\hline & Top dressing & 6.20 & 198.28 & 124.75 & 5.40 & 194.73 & 121.75 \\
\hline \multicolumn{2}{|c|}{ Mean } & 5.74 & 193.91 & 122.50 & 5.28 & 185.74 & 119.50 \\
\hline \multirow{3}{*}{$\begin{array}{l}120 \text { without } \\
\text { starting } \\
\text { fertilizer }\end{array}$} & Broadcasting & 4.88 & 200.43 & 142.75 & 4.95 & 188.48 & 135.50 \\
\hline & Side dressing & 5.00 & 197.63 & 142.25 & 4.80 & 196.58 & 140.25 \\
\hline & Top dressing & 5.35 & 208.73 & 145.50 & 5.08 & 204.83 & 144.75 \\
\hline \multicolumn{2}{|c|}{ Mean } & 5.08 & 202.26 & 143.50 & 4.94 & 196.63 & 140.17 \\
\hline \multirow{3}{*}{$\begin{array}{l}120 \text { with } \\
\text { starting } \\
\text { fertilizer }\end{array}$} & Broadcasting & 5.28 & 209.73 & 144.75 & 5.20 & 209.68 & 139.75 \\
\hline & Side dressing & 5.65 & 213.68 & 147.50 & 5.93 & 205.95 & 142.50 \\
\hline & Top dressing & 6.05 & 220.60 & 148.00 & 6.28 & 218.85 & 148.00 \\
\hline \multicolumn{2}{|c|}{ Mean } & 5.66 & 214.67 & 146.75 & 5.80 & 211.49 & 143.42 \\
\hline \multirow{3}{*}{$\begin{array}{l}\text { Means for } \\
\text { application } \\
\text { methods }\end{array}$} & Broadcasting & 4.84 & 179.69 & 122.88 & 4.79 & 174.89 & 120.58 \\
\hline & Side dressing & 5.04 & 182.70 & 125.00 & 4.98 & 180.77 & 122.92 \\
\hline & Top dressing & 5.33 & 189.15 & 126.83 & 5.24 & 189.33 & 125.67 \\
\hline \multirow{3}{*}{ L.S.D. 5\% } & Interaction (AxB) & 0.34 & 7.07 & 2.77 & 0.27 & 6.24 & 3.79 \\
\hline & Broadcasting & 0.21 & 3.52 & 2.19 & 0.18 & 3.83 & 2.25 \\
\hline & Side dressing & N.S & N.S & N.S & N.S & N.S & N.S \\
\hline
\end{tabular}

NS indicate not significant at 0.05 . 
Application method of nitrogen significantly differentiated all vegetative growth characters, in both seasons, except for bulb diameter in the first season (Table 2 and 3). Addition of nitrogen by top dressing method appeared the largest values in respect to all vegetative growth stage, except for bulb diameter in the first season. While, addition of nitrogen by broadcasting method appeared the smallest values of all vegetative growth characters, in both seasons. These results revealed that adding nitrogen by top dressing method improves the efficiency by which plants take up nitrogen nutrient and consequently encourages vegetative growth characters.

The effect of the interactions between nitrogen dose and application method were insignificant for all growth characters, except for plant height in the first season. However, the highest values of all growth characters in both seasons were obtained by application of 120 $\mathrm{kg} \mathrm{N}$ with starter by top dressing method. Application of nitrogen treatment of $60 \mathrm{~kg} \mathrm{~N}$ without starting fertilizer under broadcasting method appeared the lowest values of all studied growth characters except for plant height in the first season and No. of leaves/plant in both seasons.

\section{B- Effect of nitrogen dose and application method on yield and its components characters of onion:}

Data in Table (4) reveal that nitrogen dose significantly differentiated bulb weight, total yield/fed., marketable yield/fed. and culls yield in both seasons. The highest values of bulb weight (124.85 and $111.11 \mathrm{~g}$ ), total yield (24.88 and $26.74 \mathrm{t} / \mathrm{fed}$.) and marketable yield (22.22 and $22.43 \mathrm{t} / \mathrm{fed}$.) were obtained under nitrogen dose of $120 \mathrm{~kg}$ $\mathrm{N}$ with starter fertilizer, in the first and second seasons, respectively. The lowest values of culls yield $(1.45$ and $1.60 \mathrm{t} / \mathrm{fed}$.) were obtained under nitrogen dose treatment of $60 \mathrm{~kg} \mathrm{~N} / \mathrm{fed}$. without starter fertilizer. The lowest values of bulb weight $(61.33$ and $65.59 \mathrm{~g})$ were obtained by application of $60 \mathrm{~kg} \mathrm{~N} / \mathrm{fed}$. without starter fertilizer, in the first and second seasons, respectively. The lowest values of total yield (11.58 and $11.48 \mathrm{t} / \mathrm{fed}$.) and marketable yield (9.92 and $9.88 \mathrm{t} / \mathrm{fed}$.) were obtained by application of $60 \mathrm{~kg} \mathrm{~N} / \mathrm{fed}$. with starter fertilizer or $60 \mathrm{~kg}$ $\mathrm{N} / \mathrm{fed}$. without starter fertilizer, in the first and second seasons, respectively. These results might be due to that the applying excessive nitrogen rates accelerating the photosynthesis in storage organs of bulbs which resulting in an increase in weight and size of the bulbs, which lead to an increase in onion yield. These results are in agreement with those of Sharma, 1992; Patel et al., 1992; Yadavet al., 2005; Vetayasuporn, 2006 and Al-Fraihat, 2009. From the other hand, the highest values of yield and its components under using 
starter fertilizer with higher rates of nitrogen $(122 \mathrm{~kg} / \mathrm{fed}$.) reflect the role of starter fertilizer in onion production. This result was in harmony with that found by Stone (2000), who cleared that ammonium phosphate consistently improved early growth and final yield of bulb onion compared to broadcast ammonium nitrate. The highest value of culls yield (2.58 and $2.47 \mathrm{t} / \mathrm{fed}$.) were obtained by adding $120 \mathrm{~kg} \mathrm{~N} / \mathrm{fed}$. with or without starter fertilization, in the first and second seasons, respectively.

The results in Table (4) reveal that application methods significantly differentiated bulb weight in both seasons, total yield/fed. and marketable yield/fed. in the first season, and culls yield in the second seasons. Adding nitrogen fertilizer by top dressing methods achieved the maximum values of bulb weight (91.53 and $90.41 \mathrm{~g})$, total yield (17.53 and $18.25 \mathrm{t} / \mathrm{fed}$.) and marketable yield (15.68 and 16.71 $\mathrm{t} / \mathrm{fed}$.), in the first and second seasons, respectively. Whereas, adding nitrogen fertilizer by broadcasting method achieved the minimum values of bulb weight ( 82.71 and $80.76 \mathrm{~g})$ and marketable yield (14.22 and $14.91 \mathrm{t} / \mathrm{fed}$.), in the first and second seasons, respectively. The minimum values of total yield (15.81 and $17.10 \mathrm{t} / \mathrm{fed}$.) were obtained by Adding nitrogen fertilizer by broadcasting or side dressing methods, in the first and second seasons, respectively. For the culls, the lowest values (1.60 and $1.54 \mathrm{t} / \mathrm{fed}$.) were obtained when nitrogen fertilizer was applied by broadcasting or top dressing, in the first and second seasons, respectively, while the highest values (1.81 and $1.88 \mathrm{t} / \mathrm{fed}$.) were obtained when nitrogen fertilizer was applied by top dressing or side dressing method, in the first and second seasons, respectively. These results reflect the advantage of top dressing methods as compared to broadcasting or side dressing in respect to improving nutrient use efficiency.

The interaction between nitrogen dose and application methods appeared significant effect on total yield ( $\mathrm{t} / \mathrm{fed}$.) and marketable yield (t/fed.) in both seasons, and culls yield (t/fed.) in the second season. The highest values of total yield/fed. and marketable yield/fed. were obtained by application of $120 \mathrm{~kg} / \mathrm{fed}$. with starter fertilizer and using top dressing method, in both seasons. While the lowest values were obtained by nitrogen dose treatments of $60 \mathrm{~kg} / \mathrm{fed}$. with starter fertilizer or $60 \mathrm{~kg} / \mathrm{fed}$. without starter when using side dressing methods, in the first and second seasons, respectively. The lowest values of culls yield were obtained under nitrogen dose treatments of $90 \mathrm{~kg} \mathrm{~N} / \mathrm{fed}$., when applied by top dressing, in both seasons. While, the lowest values were obtained under nitrogen dose treatment of $120 \mathrm{~kg} \mathrm{~N} / \mathrm{fed}$. with or without starter fertilizer, when applied by broadcasting method, in the first and second seasons, respectively. 
Table (4): Effect of nitrogen dose and application method on yield and its components of onion in 2012/2013 and 2013/2014 seasons

\begin{tabular}{|c|c|c|c|c|c|c|c|c|c|}
\hline \multirow[b]{2}{*}{$\begin{array}{l}\text { Nitrogen dose } \\
(\mathbf{k g} / \mathrm{fed} .)\end{array}$} & \multirow[b]{2}{*}{ Application method } & \multicolumn{4}{|c|}{$2012 / 2013$} & \multicolumn{4}{|c|}{$2013 / 2014$} \\
\hline & & $\begin{array}{c}\text { Bulb } \\
\text { weight } \\
\text { (g) }\end{array}$ & $\begin{array}{c}\text { Total } \\
\text { yield } \\
\text { (t/fed.) }\end{array}$ & $\begin{array}{c}\text { Market. } \\
\text { yield } \\
\text { (t/fed.) }\end{array}$ & $\begin{array}{l}\text { Culls } \\
\text { yield } \\
\text { (t/fed.) }\end{array}$ & $\begin{array}{c}\text { Bulb } \\
\text { weight } \\
\text { (g) }\end{array}$ & $\begin{array}{c}\text { Total } \\
\text { yield } \\
\text { (t/fed.) }\end{array}$ & $\begin{array}{c}\text { Market. } \\
\text { yield } \\
\text { (t/fed.) }\end{array}$ & $\begin{array}{l}\text { Culls } \\
\text { yield } \\
\text { (t/fed.) }\end{array}$ \\
\hline \multirow{3}{*}{$\begin{array}{l}60 \text { without } \\
\text { starting } \\
\text { fertilizer }\end{array}$} & Broadcasting & 56.78 & 11.30 & 9.93 & 1.38 & 61.08 & 11.43 & 9.98 & 1.45 \\
\hline & Side dressing & 59.63 & 11.73 & 10.43 & 1.30 & 61.85 & 10.88 & 9.23 & 1.65 \\
\hline & Top dressing & 67.60 & 12.55 & 10.88 & 1.68 & 73.85 & 12.13 & 10.43 & 1.70 \\
\hline \multicolumn{2}{|c|}{ Mean } & 61.33 & 11.86 & 10.41 & 1.45 & 65.59 & 11.48 & 9.88 & 1.60 \\
\hline \multirow{3}{*}{$\begin{array}{l}60 \text { with starting } \\
\text { fertilizer }\end{array}$} & Broadcasting & 55.65 & 10.80 & 9.60 & 1.20 & 67.05 & 11.83 & 10.15 & 1.68 \\
\hline & Side dressing & 61.60 & 10.28 & 8.43 & 1.85 & 68.23 & 13.53 & 11.88 & 1.65 \\
\hline & Top dressing & 72.33 & 13.68 & 11.73 & 1.95 & 76.68 & 14.20 & 12.15 & 2.05 \\
\hline \multicolumn{2}{|c|}{ Mean } & 63.19 & 11.58 & 9.92 & 1.67 & 70.65 & 13.18 & 11.39 & 1.79 \\
\hline \multirow{3}{*}{$\begin{array}{l}90 \text { without } \\
\text { starting } \\
\text { fertilizer }\end{array}$} & Broadcasting & 72.93 & 14.83 & 13.90 & 0.93 & 74.70 & 14.60 & 13.53 & 1.08 \\
\hline & Side dressing & 76.13 & 14.03 & 13.03 & 1.00 & 72.55 & 14.23 & 12.95 & 1.28 \\
\hline & Top dressing & 79.15 & 12.65 & 11.80 & 0.85 & 80.35 & 14.23 & 13.20 & 1.03 \\
\hline \multicolumn{2}{|c|}{ Mean } & 76.07 & 13.83 & 12.91 & 0.93 & 75.87 & 14.35 & 13.23 & 1.13 \\
\hline \multirow{3}{*}{$\begin{array}{l}90 \text { with starting } \\
\text { fertilizer }\end{array}$} & Broadcasting & 76.15 & 13.48 & 12.58 & 0.90 & 79.20 & 15.40 & 14.15 & 1.25 \\
\hline & Side dressing & 80.63 & 14.30 & 13.40 & 0.90 & 83.15 & 16.48 & 15.33 & 1.15 \\
\hline & Top dressing & 82.15 & 14.63 & 13.43 & 1.20 & 85.53 & 16.65 & 15.48 & 1.18 \\
\hline \multicolumn{2}{|r|}{ Mean } & 79.64 & 14.13 & 13.13 & 1.00 & 82.63 & 16.18 & 14.98 & 1.19 \\
\hline \multirow{3}{*}{$\begin{array}{l}120 \text { without } \\
\text { starting } \\
\text { fertilizer }\end{array}$} & Broadcasting & 110.85 & 22.30 & 19.95 & 2.35 & 96.08 & 27.38 & 24.45 & 2.93 \\
\hline & Side dressing & 111.90 & 22.48 & 19.88 & 2.60 & 97.73 & 21.03 & 18.15 & 2.88 \\
\hline & Top dressing & 118.70 & 24.20 & 21.55 & 2.65 & 106.40 & 24.43 & 22.83 & 1.60 \\
\hline \multicolumn{2}{|c|}{ Mean } & 113.82 & 22.99 & 20.46 & 2.53 & 100.07 & 24.28 & 21.81 & 2.47 \\
\hline \multirow{3}{*}{$\begin{array}{l}120 \text { with } \\
\text { starting } \\
\text { fertilizer }\end{array}$} & Broadcasting & 123.93 & 22.18 & 19.35 & 2.83 & 106.45 & 25.85 & 17.20 & 2.08 \\
\hline & Side dressing & 121.40 & 25.03 & 22.63 & 2.40 & 107.23 & 26.48 & 23.88 & 2.68 \\
\hline & Top dressing & 129.23 & 27.45 & 24.68 & 2.53 & 119.65 & 27.90 & 26.20 & 1.70 \\
\hline \multicolumn{2}{|r|}{ Mean } & 124.85 & 24.88 & 22.22 & 2.58 & 111.11 & 26.74 & 22.43 & 2.15 \\
\hline \multirow{3}{*}{$\begin{array}{l}\text { Means for } \\
\text { application } \\
\text { methods }\end{array}$} & Broadcasting & 82.71 & 15.81 & 14.22 & 1.60 & 80.76 & 17.75 & 14.91 & 1.74 \\
\hline & Side dressing & 85.21 & 16.30 & 14.63 & 1.68 & 81.79 & 17.10 & 15.23 & 1.88 \\
\hline & Top dressing & 91.53 & 17.53 & 15.68 & 1.81 & 90.41 & 18.25 & 16.71 & 1.54 \\
\hline \multirow{3}{*}{ L.S.D. 5\% } & $\mathrm{N}$ doses $(\mathrm{A})$ & 3.26 & 1.61 & 1.60 & 0.30 & 5.66 & 1.57 & 2.79 & 0.32 \\
\hline & Appl. methods (B) & 2.74 & 1.03 & 1.06 & N.S & 3.29 & N.S & N.S & 0.22 \\
\hline & Interaction (AxB) & N.S & 2.52 & 2.60 & N.S & N.S & 2.47 & 4.65 & 0.53 \\
\hline
\end{tabular}

NS indicate not significant at 0.05 .

\section{C- Effect of nitrogen dose and application method on quality of onion bulbs:}

The results in Table (5) revealed that TSS \% and dry matter \% were significantly affected by nitrogen dose, in both seasons. Adding of $120 \mathrm{~kg} \mathrm{~N} / \mathrm{fed}$. with starter fertilizer achieved the maximum values of TSS\% in both seasons and dry matter \% in the second season, whereas, the maximum value of dry matter \%, in the first season was achieved by application of $120 \mathrm{~kg} \mathrm{~N} / \mathrm{fed}$. without starter fertilizer treatment. The minimum values of TSS\% in the first season and of dry matter in both seasons were achieved under application treatment of $60 \mathrm{~kg} \mathrm{~N} / \mathrm{fed}$. without starter fertilizer. Adding of $90 \mathrm{~kg} \mathrm{~N} / \mathrm{fed}$. without starter fertilizer achieved the minimum value of TSS\% in the second season. These positive effect of nitrogen fertilization on onion TSS\% was in accordance with that recorded by Moursyet al. (2007) who showed that increasing the level of $\mathrm{N}$ fertilizer to $80 \mathrm{Kg} \mathrm{N} / \mathrm{fed}$. resulted in about $8.5 \%$ increase in the T.S.S\% as compared to the level of 40 $\mathrm{Kg} \mathrm{N} / \mathrm{fed}$. Whereas, these results were in disadvantage with that found by Hanna-Allaet al. (1991), who cleared that increasing nitrogen levels up to $120 \mathrm{Kg} / \mathrm{fed}$. decreased the percentage of T.S.S\% of mature bulbs Giza 20 cv. 
Table (5): Effect of nitrogen dose and application method on onion bulbs quality in 2012/2013 and 2013/2014 seasons

\begin{tabular}{|c|c|c|c|c|c|}
\hline \multirow{2}{*}{$\begin{array}{l}\text { Nitrogen dose } \\
(\mathbf{k g} / \mathrm{fed} .)\end{array}$} & \multirow{2}{*}{$\begin{array}{l}\text { Application } \\
\text { method }\end{array}$} & \multicolumn{2}{|c|}{$2012 / 2013$} & \multicolumn{2}{|c|}{$2013 / 2014$} \\
\hline & & TSS $\%$ & Dry matter\% & TSS $\%$ & Dry matter\% \\
\hline \multirow{3}{*}{$\begin{array}{c}60 \text { without } \\
\text { starting } \\
\text { fertilizer }\end{array}$} & Broadcasting & 9.80 & 9.35 & 11.15 & 9.85 \\
\hline & Side dressing & 9.83 & 9.55 & 11.25 & 10.50 \\
\hline & Top dressing & 10.03 & 10.80 & 11.88 & 11.95 \\
\hline \multicolumn{2}{|c|}{ Mean } & 9.88 & 9.90 & 11.43 & 10.77 \\
\hline \multirow{3}{*}{$\begin{array}{l}60 \text { with } \\
\text { starting fertilizer }\end{array}$} & Broadcasting & 10.03 & 9.75 & 10.58 & 10.98 \\
\hline & Side dressing & 10.05 & 10.65 & 10.98 & 11.08 \\
\hline & Top dressing & 10.65 & 10.20 & 11.83 & 12.18 \\
\hline \multicolumn{2}{|c|}{ Mean } & 10.24 & 10.20 & 11.13 & 11.41 \\
\hline \multirow{3}{*}{$\begin{array}{l}90 \text { without starting } \\
\text { fertilizer }\end{array}$} & Broadcasting & 11.75 & 12.63 & 10.68 & 11.60 \\
\hline & Side dressing & 10.80 & 11.40 & 11.13 & 11.93 \\
\hline & Top dressing & 11.38 & 12.95 & 10.93 & 12.05 \\
\hline \multicolumn{2}{|c|}{ Mean } & 11.31 & 12.33 & 10.91 & 11.86 \\
\hline \multirow{3}{*}{$\begin{array}{l}90 \text { with } \\
\text { starting fertilizer }\end{array}$} & Broadcasting & 10.98 & 11.93 & 10.98 & 10.73 \\
\hline & Side dressing & 11.48 & 12.80 & 11.53 & 12.18 \\
\hline & Top dressing & 12.20 & 13.58 & 11.70 & 12.40 \\
\hline \multicolumn{2}{|c|}{ Mean } & 11.55 & 12.77 & 11.40 & 11.77 \\
\hline \multirow{3}{*}{$\begin{array}{l}120 \text { without starting } \\
\text { fertilizer }\end{array}$} & Broadcasting & 13.25 & 15.08 & 12.45 & 13.35 \\
\hline & Side dressing & 12.65 & 14.38 & 13.13 & 13.25 \\
\hline & Top dressing & 12.00 & 14.00 & 13.70 & 13.98 \\
\hline \multicolumn{2}{|c|}{ Mean } & 13.12 & 15.00 & 13.09 & 13.53 \\
\hline \multirow{3}{*}{$\begin{array}{l}120 \text { with starting } \\
\text { fertilizer }\end{array}$} & Broadcasting & 13.58 & 14.68 & 12.65 & 13.33 \\
\hline & Side dressing & 14.43 & 14.70 & 13.80 & 13.85 \\
\hline & Top dressing & 14.08 & 14.90 & 14.55 & 14.48 \\
\hline \multicolumn{2}{|c|}{ Mean } & 14.03 & 14.76 & 13.67 & 13.88 \\
\hline \multirow{3}{*}{$\begin{array}{l}\text { Means for } \\
\text { application } \\
\text { methods }\end{array}$} & Broadcasting & 11.56 & 12.23 & 11.41 & 11.64 \\
\hline & Side dressing & 11.54 & 12.25 & 11.97 & 12.13 \\
\hline & Top dressing & 11.96 & 13.00 & 12.43 & 12.84 \\
\hline \multirow{3}{*}{ L.S.D. $5 \%$} & $\mathrm{~N}$ doses $(\mathrm{A})$ & 0.40 & 0.50 & 0.61 & 0.72 \\
\hline & Appl. methods (B) & 0.32 & 0.40 & 0.35 & 0.40 \\
\hline & Interaction (AxB) & N.S & 0.97 & N.S & N.S \\
\hline
\end{tabular}

NS indicate not significant at 0.05 .

Data in Table (5) reveal that application methods differentiated TSS $\%$ and dry matter $\%$ in both seasons. The largest values of TSS $\%$ and dry matter \% were obtained by adding nitrogen fertilizer by top dressing methods, in both seasons. The smallest values of TSS\% in the second season and dry matter \% in both seasons were obtained by adding nitrogen fertilizer by dressing methods.

The interaction between nitrogen dose and application method had insignificant effect on TSS\% in both seasons, while it had significant effect on dry matter \% on the first season only. The best combination in the first season in respect to dry matter \% was obtained by adding $120 \mathrm{~kg} \mathrm{~N} / \mathrm{fed}$. without starter fertilizer and using broadcasting method; while, the best combination in the second seasons was obtained by adding $120 \mathrm{~kg} \mathrm{~N} / \mathrm{fed}$. with starter fertilizer, and using top dressing method. The worst combinations were obtained by adding $60 \mathrm{~kg} \mathrm{~N} / \mathrm{fed}$. without starter fertilizer and using broadcasting method in both seasons.

\section{D- Effect of nitrogen doses and application method on the storability of onion bulbs:}

Data presented in Table (6) clear that weight loss\% of stored bulbs for 2, 4 and 6 months were significantly affected by nitrogen 
dose at all storage periods, in both seasons. After storing bulbs for two months the lowest values of weight loss \% were observed under nitrogen dose treatment of $60 \mathrm{~kg} \mathrm{~N} / \mathrm{fed}$. without starter fertilizer, in both seasons, while, the highest values were observed under nitrogen dose treatment of $120 \mathrm{~kg} \mathrm{~N} / \mathrm{fed}$. with starter fertilizer in the first season, and under treatment of $120 \mathrm{~kg} \mathrm{~N} / \mathrm{fed}$. without starter fertilizer, in the second season. These results detected that excessive nitrogen application increased loss\% after two months storage period. These results may be explained in view that onion bulbs grown under high $\mathrm{N}$ dose tend to rot and sprout early during storage than those grown under optimum dose. These results were supported by the findings of Brewster (1994), who showed that excessive $N$ application contributes to increased storage losses, and Batal et al. (1994), who reported that high levels of nitrogen fertilization promote sprouting and decay of onions. After storing for four months, the lowest weight loss $\%$ were obtained under nitrogen dose treatments of $120 \mathrm{~kg} \mathrm{~N} / \mathrm{fed}$. with starter fertilizer in the first season and $60 \mathrm{~kg} \mathrm{~N} / \mathrm{fed}$. without starting fertilizer in the second seasons. The highest values of weight loss $\%$ were obtained under nitrogen dose treatments of $120 \mathrm{~kg} \mathrm{~N} / \mathrm{fed}$. without starting fertilizer in first season, and $120 \mathrm{~kg} \mathrm{~N} / \mathrm{fed}$. with starter fertilizer in second season.

After storing for six months, the minimum values of weight loss $\%$ were obtained under nitrogen dose treatments of $120 \mathrm{~kg} \mathrm{~N} / \mathrm{fed}$. with starter fertilizer in the first season, and under $90 \mathrm{~kg} \mathrm{~N} / \mathrm{fed}$ with starter fertilizer in second season. While the maximum values were obtained under nitrogen dose treatments of $90 \mathrm{~kg} \mathrm{~N} / \mathrm{fed}$ without starter fertilizer in first season and $60 \mathrm{~kg} \mathrm{~N} / \mathrm{fed}$ without starter fertilizer in second seasons. Data presented in Table (6) clear that weight loss\% of stored bulbs for 2, 4 and 6 months were significantly affected by nitrogen application method in both seasons. Application of nitrogen by top dressing appeared the lowest values of weight loss\% after storing for 2, 4 and 6 months, in both season. While, application of nitrogen by broadcasting method appeared the highest values of weight loss $\%$ after all storing period, in both seasons, except for weight loss $\%$ after 2 months in first seasons. These results reflect the benefit of top dressing methods as compared to broadcasting or side dressing in improving nitrogen use efficiency during growth season of onion which resulted in bulbs with high quality can tolerate the storing for long periods. 
Table (6): Effect of nitrogen dose treatments and application methods on loss $\%$ of onion bulbs after 2, 4 and 6 months of storage in 2012/2013 and 2013/2014 seasons

\begin{tabular}{|c|c|c|c|c|c|c|c|}
\hline \multirow{3}{*}{$\begin{array}{l}\text { Nitrogen dose } \\
\quad(\mathbf{k g} / \mathrm{fed} .)\end{array}$} & \multirow{3}{*}{$\begin{array}{l}\text { Application } \\
\text { methods }\end{array}$} & \multicolumn{3}{|c|}{$2012 / 2013$} & \multicolumn{3}{|c|}{ 2013/2014 } \\
\hline & & \multicolumn{6}{|c|}{ Loss $\%$ after } \\
\hline & & 2 months & 4 months & 6 months & 2 months & 4 months & 6 months \\
\hline \multirow{3}{*}{$\begin{array}{c}60 \text { without } \\
\text { Starting fertilizer }\end{array}$} & Broadcasting & 4.35 & 15.55 & 37.75 & 3.79 & 14.31 & 39.44 \\
\hline & Side dressing & 3.62 & 16.62 & 36.13 & 3.68 & 15.22 & 40.78 \\
\hline & Top dressing & 2.77 & 14.30 & 36.39 & 3.36 & 13.74 & 36.71 \\
\hline \multicolumn{2}{|c|}{ Mean } & 3.58 & 15.49 & 36.76 & 3.61 & 14.42 & 38.98 \\
\hline \multirow{3}{*}{$\begin{array}{l}60 \text { with } \\
\text { starting fertilizer }\end{array}$} & Broadcasting & 3.26 & 16.67 & 37.64 & 4.11 & 16.18 & 35.43 \\
\hline & Side dressing & 3.83 & 15.30 & 34.95 & 3.99 & 14.58 & 36.25 \\
\hline & Top dressing & 4.06 & 14.07 & 29.96 & 3.56 & 13.22 & 32.29 \\
\hline \multicolumn{2}{|c|}{ Mean } & 3.71 & 15.34 & 34.18 & 3.89 & 14.66 & 34.65 \\
\hline \multirow{3}{*}{$\begin{array}{c}90 \text { without } \\
\text { starting fertilizer }\end{array}$} & Broadcasting & 6.01 & 17.45 & 41.17 & 6.94 & 19.18 & 38.58 \\
\hline & Side dressing & 5.30 & 15.54 & 36.68 & 6.28 & 18.07 & 37.30 \\
\hline & Top dressing & 4.19 & 13.82 & 33.05 & 5.03 & 15.11 & 33.01 \\
\hline \multicolumn{2}{|c|}{ Mean } & 5.17 & 15.60 & 36.96 & 6.09 & 17.45 & 36.30 \\
\hline \multirow{3}{*}{$\begin{array}{l}90 \text { with } \\
\text { starting fertilizer }\end{array}$} & Broadcasting & 5.65 & 15.18 & 35.44 & 5.73 & 17.96 & 32.42 \\
\hline & Side dressing & 4.59 & 15.77 & 31.83 & 5.18 & 15.22 & 31.99 \\
\hline & Top dressing & 4.39 & 12.50 & 30.48 & 4.28 & 13.91 & 31.67 \\
\hline \multicolumn{2}{|c|}{ Mean } & 4.88 & 14.49 & 32.59 & 5.06 & 15.69 & 32.03 \\
\hline \multirow{3}{*}{$\begin{array}{l}120 \text { without starting } \\
\text { fertilizer }\end{array}$} & Broadcasting & 15.38 & 24.38 & 38.61 & 16.50 & 24.38 & 38.51 \\
\hline & Side dressing & 14.50 & 22.30 & 32.86 & 15.88 & 25.32 & 37.58 \\
\hline & Top dressing & 12.36 & 19.07 & 30.83 & 14.98 & 22.03 & 33.76 \\
\hline \multicolumn{2}{|c|}{ Mean } & 14.08 & 21.92 & 34.10 & 15.79 & 23.91 & 36.62 \\
\hline \multirow{3}{*}{$\begin{array}{l}120 \text { with } \\
\text { starting fertilizer }\end{array}$} & Broadcasting & 13.25 & 16.14 & 32.34 & 18.44 & 34.62 & 35.78 \\
\hline & Side dressing & 16.89 & 12.61 & 31.95 & 14.20 & 30.69 & 33.55 \\
\hline & Top dressing & 12.27 & 9.69 & 28.24 & 12.16 & 24.48 & 30.43 \\
\hline \multicolumn{2}{|c|}{ Mean } & 14.14 & 12.81 & 30.84 & 14.93 & 29.93 & 33.25 \\
\hline \multirow{3}{*}{$\begin{array}{l}\text { Means for application } \\
\text { methods }\end{array}$} & Broadcasting & 7.98 & 17.56 & 37.16 & 9.25 & 21.10 & 36.69 \\
\hline & Side dressing & 8.12 & 16.36 & 34.06 & 8.20 & 19.85 & 36.24 \\
\hline & Top dressing & 6.67 & 13.91 & 31.49 & 7.23 & 17.08 & 32.98 \\
\hline \multirow{3}{*}{ L.S.D. 5\% } & N doses $(A)$ & 1.63 & 1.81 & 2.84 & 1.89 & 2.91 & 4.11 \\
\hline & Appl. methods (B) & 0.99 & 1.26 & 2.31 & 0.78 & 1.35 & 2.68 \\
\hline & Interaction (AxB) & N.S & N.S & N.S & 1.91 & 3.31 & N.S \\
\hline
\end{tabular}

NS indicate not significant at 0.05 .

In respect to the interaction effect, data in Table (6) show that bulbs weight loss $\%$ was insignificantly affected by the interaction between nitrogen dose treatments and application methods at 2, 4 and 6 months in both seasons, except for that at 2 and 4 months in second season. The lowest values of bulbs weight loss $\%$ at 2 and 4 months in the second season were obtained by application of $60 \mathrm{~kg} \mathrm{~N} / \mathrm{fed}$.without starter fertilizer or $60 \mathrm{~kg} \mathrm{~N} / \mathrm{fed}$. without starter fertilizer by top dressing, in first and second seasons, respectively. The highest values of weight loss\% after 2 and 4 months were obtained by application of $120 \mathrm{~kg}$ $\mathrm{N} /$ fed. with starter fertilizer when applied by broadcasting method, in both seasons.

\section{E- Economic analysis:}

Data cited in Table (7) showed that the beneficial cost ratio of using $120 \mathrm{~kg} \mathrm{~N} / \mathrm{fed}$. with starter fertilizer by top dressing could be attributed to the fact that more marketable onion yield were produced per unit area, higher gross and net returns (30442 and 22212 L.E./fed., respectively) compared with other treatments. Also, from the economic point of view, the revenue of L.E. is higher when used $120 \mathrm{~kg} \mathrm{~N} / \mathrm{fed}$. 
without starter fertilizer and using broadcasting method which give the best benefit: cost ratio (3.70). The worst combinations were obtained by adding $60 \mathrm{~kg} \mathrm{~N} / \mathrm{fed}$ without starter fertilizer and using broadcasting method in both seasons.

Table (7): Average cost cultivation, gross return and net return (L.E./ fed.) as well as benefit: cost ratio of onion yield as influenced by different $\mathrm{N}$ fertilizer dose and application method as overall mean values through the two growing seasons

\begin{tabular}{|c|c|c|c|c|c|}
\hline $\begin{array}{l}\text { Nitrogen dose } \\
\quad(\mathbf{k g} / \mathrm{fed} .)\end{array}$ & Application method & $\begin{array}{l}\text { Costs of } \\
\text { cultivation } \\
\text { (L.E./fed.) }\end{array}$ & $\begin{array}{l}\text { Gross return } \\
\text { (L.E./ fed.) }\end{array}$ & $\begin{array}{l}\text { Net return } \\
\text { (L.E./fed.) }\end{array}$ & $\mathrm{B}: \mathrm{C}$ ratio \\
\hline \multirow{3}{*}{$\begin{array}{l}60 \text { without starting } \\
\text { fertilizer }\end{array}$} & Broadcasting & 7900 & 12501 & 4601 & 1.58 \\
\hline & Side dressing & 7900 & 12435 & 4535 & 1.57 \\
\hline & Top dressing & 7900 & 13574 & 5674 & 1.72 \\
\hline \multicolumn{2}{|c|}{ Mean } & 7900 & 12837 & 4937 & 1.62 \\
\hline \multirow{3}{*}{$\begin{array}{c}60 \text { with } \\
\text { starting fertilizer }\end{array}$} & Broadcasting & 7900 & 12446 & 4546 & 1.58 \\
\hline & Side dressing & 7900 & 13095 & 5195 & 1.66 \\
\hline & Top dressing & 7900 & 15334 & 7434 & 1.94 \\
\hline \multicolumn{2}{|c|}{ Mean } & 7900 & 13625 & 5725 & 1.72 \\
\hline \multirow{3}{*}{$\begin{array}{l}90 \text { without starting } \\
\text { fertilizer }\end{array}$} & Broadcasting & 8065 & 16186 & 8121 & 2.01 \\
\hline & Side dressing & 8065 & 15543 & 7478 & 1.93 \\
\hline & Top dressing & 8065 & 14784 & 6719 & 1.83 \\
\hline \multicolumn{2}{|c|}{ Mean } & 8065 & 15504 & 7439 & 1.92 \\
\hline \multirow{3}{*}{$\begin{array}{c}90 \text { with } \\
\text { starting fertilizer }\end{array}$} & Broadcasting & 8065 & 15884 & 7819 & 1.97 \\
\hline & Side dressing & 8065 & 16929 & 8864 & 2.10 \\
\hline & Top dressing & 8065 & 17204 & 9139 & 2.13 \\
\hline \multicolumn{2}{|c|}{ Mean } & 8065 & 16672 & 8607 & 2.07 \\
\hline \multirow{3}{*}{$\begin{array}{l}120 \text { without } \\
\text { starting fertilizer }\end{array}$} & Broadcasting & 8230 & 27324 & 19094 & 3.32 \\
\hline & Side dressing & 8230 & 23930 & 15700 & 2.91 \\
\hline & Top dressing & 8230 & 26746 & 18516 & 3.25 \\
\hline \multicolumn{2}{|c|}{ Mean } & 8230 & 26000. & 17770 & 3.16 \\
\hline \multirow{3}{*}{$\begin{array}{l}120 \text { with starting } \\
\text { fertilizer }\end{array}$} & Broadcasting & 8230 & 26416 & 18186 & 3.21 \\
\hline & Side dressing & 8230 & 28330 & 20100 & 3.44 \\
\hline & Top dressing & 8230 & 30442 & 22212 & 3.70 \\
\hline \multicolumn{2}{|c|}{ Mean } & 8230 & 28396 & 20166 & 3.45 \\
\hline \multirow{3}{*}{$\begin{array}{l}\text { Means for } \\
\text { application } \\
\text { methods }\end{array}$} & Broadcasting & 8065 & 1846 & 10394 & 2.28 \\
\hline & Side dressing & 8065 & 18377 & 10312 & 2.26 \\
\hline & Top dressing & 8065 & 19680 & 11615 & 2.43 \\
\hline
\end{tabular}

\section{REFERENCES}

Abbes, C.; L. E. Parent; A. Karam and D. Isfan (1995). Effect of $\mathrm{NH} 4^{+}: \mathrm{NO}^{-}{ }^{-}$ratios on growth and nitrogen uptake by onions. Plant and Soil 171, 289-296.

Abdissa, Y.; T. Tekalign and L. M. Pant (2011). Growth, bulb yield and quality of onion (Allium cepa L.) as influenced by nitrogen and phosphorus fertilization on vertisol I. growth attributes, biomass production and bulb yield. African Journal of Agricultural Research, 6 (14): 3252 - 3258.

Al-Fraihat, A. H. (2009). Effect of different nitrogen and sulphur fertilizer levels on growth, yield and quality of onion (Allium cepa, L.). Jordan Journal of Agricultural Sciences, 5 (2): 155-166.

A.O.A.C. (1975). "Official Methods of Analysis of the Association of Official Agriculture Chemists". Twelfth Ed. published by the Association of Official Agriculture Chemists. Washington, D.C. 832.

Balemi, T.; N. Pal and A. K. Saxena (2007). Response of onion (Allium cepa L.) to combined application of biological and chemical 
nitrogenous fertilizers.ActaAgriculturaeSlovenica, 89 (1), str. 107114.

Batal, K. M.; K. Bondary; D. M. Granberry and B.G. Mullinix (1994). Effects of source, rate and frequency of $\mathrm{N}$ application on yield, marketable grades and rot incidence of sweet onion (Allium cepa L. cv. Granex-33). Journal of Horticultural Science 69, 1043-1051.

Brewester, J. L. (1994). Onions and other vegetable Alliums. CAB International, Wallingford, UK, p. 236.

Brewster, J.L. (2008). Onions and other Vegetable Alliums, 2nd Edition Library of Congress Cataloging-in-Publication Data, Crop production science in horticulture series (15), Chapter 6 (Agronomy and Crop Production) 256-259 ppt.

Brewster, J. L., Rowse, H.R. and Bosch, A.D. (1992). The effects of subseed placement of liquid $\mathbf{N}$ and $\mathbf{P}$ fertilizer on the growth and development of bulb onions over a range of plant densities using primed and non-primed seed. Journal of Horticultural Science 66, 551-557.

Burns, I.G. (1990). The effects of continuity of early nitrogen nutrition on growth and development of Lactuca sativa. In: Plant Nutrition Physiology and Applications (ed. van Beusichem) Kluwer Academic Publishers, Dordrecht, pp. 545-549.

Devlin, R.M. and F.H. Withan (1986). Plant physiology, $4^{\text {th }}$ Ed. CBS publishers and distributor 485, Jain Bhawan, Shadhara, Delhi, 110032 (India).

El-Oksh, I. I.; A. M. El - Gizawy and M. M. Abdallah (1993). Effect of soil moisture and nitrogen fertilizer level on onion grown on mixture tafla and sanot (1-7). Bull. Fac. Agric. Cairo Univ. 44(1): 145-156.

Halvorson, A. D.; R. F. Follett, M. E. Bartolo and F. C. Schweissing (2001). Nitrogen Fertilizer Use Efficiency of Furrow-Irrigated Onion and Corn. Agronomy Journan, 94 (3): 442-449.

Hanna-Alla, M.H.; A.K. El-Kafoury; M.Y. Ibrahim and M.M. ElGammal.(1991). Effect of nitrogen fertilizer levels on bulb yield and quality of some onion cultivars.Minufiya J. Agric. Res. 16(2): 16371644.

Latif, A.; Z. Iqbal; S. Ali and M.M. Iqbal (2003). Improvement in phosphorus fertilizer efficiency by fertigation in some winter vegetable. Pakistan Journal of Soil Science 22: 81-85.

Mohamed, G.A.; and A.A. Hemida (2004). Response of Giza 6 Mohassan onion to some irrigation and nitrogen fertilization treatments.Minia J. of Agric. Res. and Develop., 24 (2): 177-190.

Moursy, M. El.; H. E. Khalifa; M. M. Attia; M. A. Sayed and A. M. Osman (2007). Effect of organic and nitrogen fertilizers and plant densities on onion production in sandy soils under drip irrigation system. Alex. J. Agric. Res. 52 (1): 103-108.

Patel, K.P.; J. C. Patel; B. S. Patel; and S. G. Sadaria (1992). Yield and nutrient uptake by onion (Allium cepa $L$.) as influenced by irrigation, nitrogen and phosphorus. Indian J. Agron., 37: 395-396. 
Sharma, R.P. (1992). Effect of planting material, nitrogen and potash on bulb yield of rainy season onion (Allium cepa L.). Indian J. Agron., 37: 868-869.

Snedecor, G.V. and W.G. Cochran (1980). Statistical methods, $12^{\text {th }}$ Ed. lowa State Univ. Press, Amer. lowa, USA.

Stone, D. A. (2000). The effects of starter fertilizers on the growth and nitrogen use efficiency of onion and lettuce. Soil Use and Management 16, 42-48.

Stone, D.A. (1998). The effects of 'starter' fertilizer injection on the growth and yield of drilled vegetable crops in relation to soil nutrient status. Journal of Horticultural Science and Biotechnology 73, 441-451.

Vetayasuporn, S. (2006). Effect of biological and chemical fertilizers on growth and yield of shallot (Allium cepavar.Ascolonicum) production. J. of Biological Sci.,6(1): 82-86.

Walter, R.A. and D.E. Duncan (1969). A bay rule for the symmetric multiple comparison problem. Amer. State Assoc. Jour. Dec., 1485-1503.

Watson, G. (2010). The effect of broadcast nitrogen fertilization rates and placement on the growth of green ash trees.Arboriculture\& Urban Forestry. 36(4): 179-182.

Woldetsadik, K.; U. Gertsson and J. Ascard (2003). Response of shallots to mulching and nitrogen fertilization. Hort. Science 38 (2): 217-221.

Yadav, B.D.; R. B. Khandewal and Y. K. Sharma (2005). Use of biofertilizer (Azospirillium) in onion. Indian J. Hort.,62(2): 168-170.

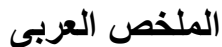

$$
\begin{aligned}
& \text { تأثير بعض معاملات التسميد النيتروجينى وطرق التربى الاضافة على النمو }
\end{aligned}
$$

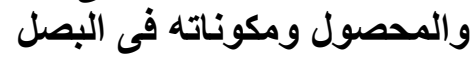

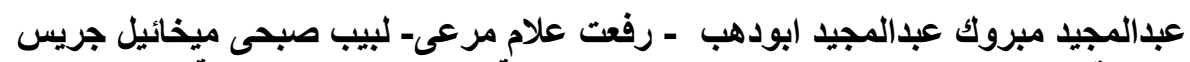

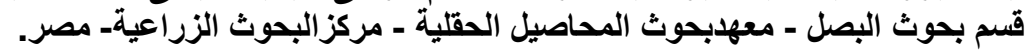

$$
\begin{aligned}
& \text { اجريت هذه الدراسة بمحطة البحوث الزراعية بسدس - محافظة بنى سويف روذلك فى في }
\end{aligned}
$$

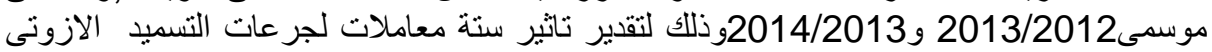

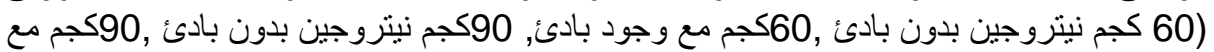

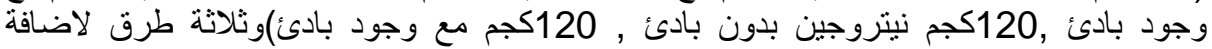

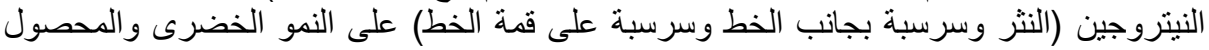

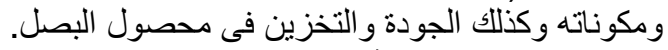

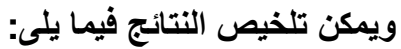

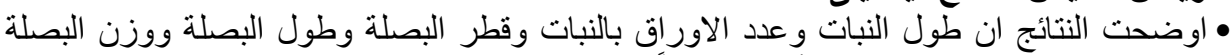

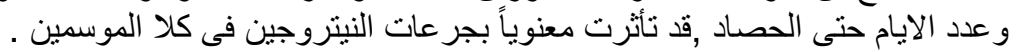

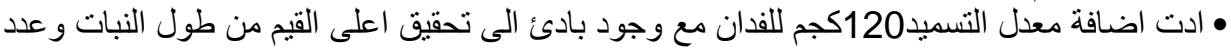

$$
\begin{aligned}
& \text { الاور اق بالنبات وقطر البصلة ووزن النبات و عدد الايام حتى النضجفى كلا الموسئ اعلى المين. }
\end{aligned}
$$


• ادت اضافة النيتروجين بطريقة السرسبة على قمة الخط الى تحقيق اعلى القيم لكل صفات النموفيما

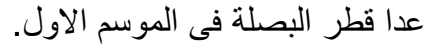

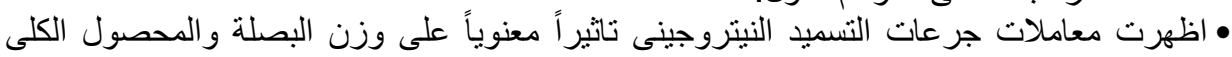

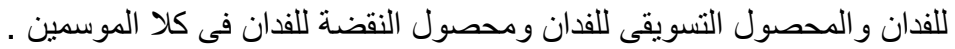

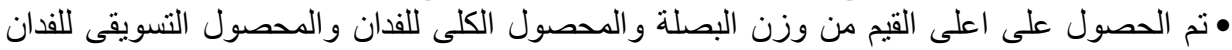

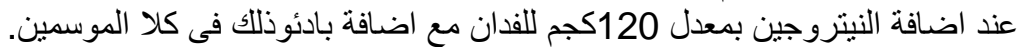

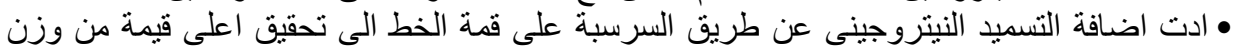

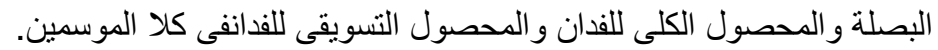

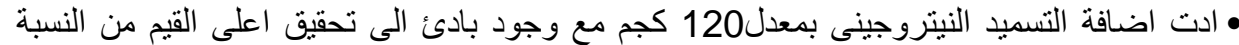
المئوية للمواد الصلبة الذائبة الكلية فى كلا الموسمين ,والنسبة المئوية للمادة الصلبة فى الموسم اعلية • تم الحصول على اعلى القيم من النسبة المئوية للمواد الصلبة الذائبة الكلية والنسبة المئوية للمادة

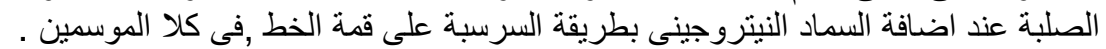

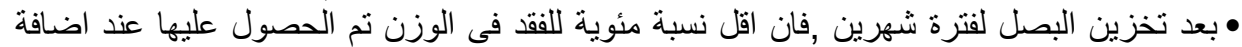

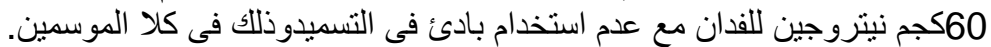

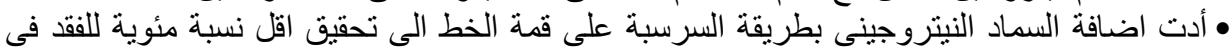

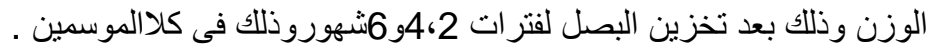

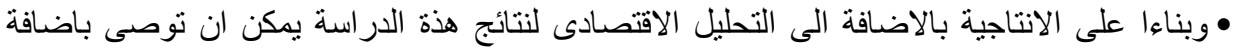

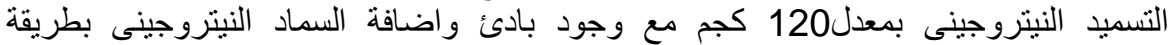

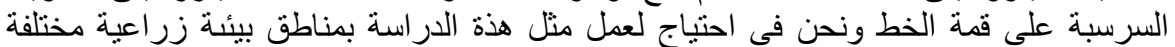

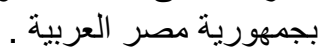

